\title{
EPIDEMIOLOGICAL AND CLINICAL CHARACTERISTICS OF SCORPION STINGS IN CHILDREN IN FEZ, MOROCCO
}

\section{Abourazzak S (1), Achour S (2), El Arqam L (1), Atmani S (1), Chaouki S (1), Semlali I (2), Soulaymani Bencheikh R (2), Bouharrou A (1), Hida M (1)}

(1) Department of Pediatrics, Hassan II University Hospital Center, Fez, Morocco; (2) Poison Control and Pharmacovigilance Center of Morocco, Rabat Institute, Madinat Al Irfane, Rabat, Morocco.

ABSTRACT: Scorpion stings are a public health problem in Morocco, especially among children, who experience the most severe cases. Epidemiological and clinical findings on scorpion stings in Fez, Morocco, were evaluated in this investigation. Of 163 cases that required medical attention, $62.6 \%$ were male children. The mean age of patients was $4.8 \pm 3.4$ years. The mean time between stings and first medical attention was $3.36 \pm 2.5$ hours. Almost all cases occurred in the summer (94\%) and extremities represented the most frequent sting sites (86.5\%). Local pain, hyperemia, scarification, vomiting, sweating, restlessness, tachycardia and tachypnea were the observed clinical symptoms. Regarding severity, $55.2 \%$ of patients belonged to class III, followed by class II (26.4\%) and class I (18.4\%). None of our patients received antivenom; however, all of them were treated symptomatically depending on clinical manifestations.

KEY WORDS: scorpion sting, clinical symptoms, envenomation, treatment, children, Morocco.

CONFLICTS OF INTEREST: There is no conflict.

\section{CORRESPONDENCE TO:}

SANA ABOURAZZAK, Department of Pediatrics, Hassan II University Hospital, Fez 30 000, Morocco. Phone: +212 676654 05. Fax: +212 359322 74. Email: abourazzak77@yahoo.fr. 


\section{INTRODUCTION}

Scorpion envenomation is a major public health problem in Morocco that provokes numerous deaths, especially in the southwest region. The Moroccan Poison Control Center reports that scorpion stings are the most frequent cause of envenomations in the country, representing between 30 and $50 \%$ of all registered cases. Currently, 25,000 scorpion stings are recorded per year in Morocco and $90 \%$ of fatal cases are younger than 10 years old (1). The highest mortality rates, up to $5.3 \%$, are observed in south and south-central provinces of the country.

This study aimed to describe epidemiological characteristics of scorpion envenomation in children in the region of Fez, situated in the midwest of Morocco, where health care is relatively more accessible and functional than in mountainous regions.

\section{PATIENTS AND METHODS}

\section{Subjects and Data Collection}

This retrospective study was conducted during 2004, 2005, 2006 and 2007 in the emergency room of the Children's Hospital of the Hassan II University, and included all children who utilized this department and presented envenomation by scorpion sting or who showed compatible clinical symptoms.

Clinical and epidemiological data were obtained from medical records of the Moroccan Poison Control Center and comprised demographics, sting characteristics, time elapsed between sting and admission to the hospital, clinical symptoms and vital signs from the moment of arrival until the patient was released from the hospital. Details of treatment, envenomation evolution and any complications were also registered.

\section{Classification of Symptoms}

Clinical severity was graded according to Abroug's classification (2):

- Class I: local signs including local pain, erythema and paresthesia restricted to the sting area.

- Class II: shivering, fever, excessive sweating, nausea, vomiting, diarrhea, hypertension and priapism. 
- Class III: cardiovascular, respiratory or neurological symptoms (such as cardiogenic shock, pulmonary edema, altered consciousness and convulsive crisis).

\section{Statistics}

Data were analyzed using the Epi Info 6® software (CDC, USA). Statistical analysis was carried out with chi-squared test of independence $\left(\chi^{2}\right)$ or analysis of variance $(F)$. Results were deemed significant when the $p$ value was less than 0.05 .

\section{RESULTS}

\section{Epidemiological Findings}

Table 1 presents epidemiological characteristics of children stung by scorpions. Data were collected from 163 sting cases registered over the four years of investigation. The incidence was $1.6 \%$ while the mean age of patients was 4.8 years old (standard deviation: 3.4 ; age range: 1 month to 13 years). The highest sting incidence, $38.5 \%$, afflicted children between 4 and 10 years. Additionally, there was an unequal distribution of cases between genders, the male-to-female ratio was 17:10.

Most cases occurred during the summer period (94\%), mainly from June to September, with a peak in July (28\%). The average time elapsed between sting and admission to the hospital (time after sting - TAS) was 3.36 hours (standard deviation: 2.5 hours; time range: 0.5 to 19 hours). Furthermore, $32.5 \%$ of the victims arrived at the hospital more than four hours after their accidents.

Table 2 shows some features of the studied scorpion stings, which most commonly affected extremities (86.5\%). When the animal color was seen, the yellow scorpion was easily identified by the patients (41.7\%). Moreover, stings were distributed equally between night and day. 
Table1. Epidemiological characteristics of children stung by scorpions

\begin{tabular}{|c|c|c|}
\hline Epidemiological Characteristics & Number of Patients $(n=163)$ & Patients (\%) \\
\hline \multicolumn{3}{|l|}{ Age (months) } \\
\hline $1-6$ & 5 & 3.1 \\
\hline $6-12$ & 11 & 6.7 \\
\hline $12-24$ & 23 & 14.1 \\
\hline $24-48$ & 38 & 23.3 \\
\hline $48-120$ & 63 & 38.7 \\
\hline$\geq 120$ & 23 & 14.1 \\
\hline \multicolumn{3}{|l|}{ Sex } \\
\hline Male & 102 & 62.6 \\
\hline Female & 61 & 37.4 \\
\hline \multicolumn{3}{|l|}{ Origin } \\
\hline Fez & 35 & 21.5 \\
\hline Referred $^{*}$ & 110 & 67.5 \\
\hline Unknown & 18 & 11 \\
\hline \multicolumn{3}{|l|}{ TAS (hours)** } \\
\hline $0-1$ & 5 & 3.3 \\
\hline $1-2$ & 29 & 19.2 \\
\hline $2-3$ & 34 & 22.5 \\
\hline $3-4$ & 34 & 22.5 \\
\hline$\geq 4$ & 49 & 32.5 \\
\hline
\end{tabular}

*Mountainous regions.

** Time after sting (TAS) 
Table 2. Features of scorpion stings among the studied cases

\begin{tabular}{|c|c|c|}
\hline Characteristics & Number of Patients & Patients (\%) \\
\hline \multicolumn{3}{|l|}{ Scorpion color } \\
\hline Yellow & 68 & 41.7 \\
\hline Black & 45 & 27.6 \\
\hline Unknown & 50 & 30.7 \\
\hline \multicolumn{3}{|l|}{ Sting site } \\
\hline Lower extremity & 82 & 50.3 \\
\hline Upper extremity & 59 & 36.2 \\
\hline Face & 6 & 3.7 \\
\hline Thorax & 4 & 2.5 \\
\hline Unknown & 12 & 7.4 \\
\hline \multicolumn{3}{|l|}{ Time of sting } \\
\hline Night & 79 & 48.5 \\
\hline Day & 77 & 47 \\
\hline Unknown & 7 & 4.5 \\
\hline
\end{tabular}

\section{Clinical Findings}

Pain was present with hyperemia and scarification in almost all cases. Similarly, systemic manifestations of envenomation were present in a high proportion $(81.6 \%)$ including vomiting, sweating, restlessness, tachycardia and tachypnea (Table 3). Based on clinical evaluation, half of the patients were classified as class III severity (55.2\%), followed by class II (26.4\%) and class I (18.4\%).

A weak correlation between age and envenomation severity was observed; the younger the patient, the worse the symptoms. The average ages in cases of mild, moderate or severe envenomation were 75,58 and 50 months, respectively $(p<$ 0.05) (Table 4). 
Table 3. Clinical symptoms developed by victims of scorpion stings

\begin{tabular}{|c|c|c|}
\hline Symptoms & Number of Patients $(n=163)$ & Patients \% \\
\hline \multicolumn{3}{|l|}{ Local signs } \\
\hline Pain & 133 & 81.6 \\
\hline Hyperemia & 91 & 55.8 \\
\hline Scarification & 64 & 39.3 \\
\hline Itching & 26 & 16.0 \\
\hline Swelling & 8 & 4.9 \\
\hline \multicolumn{3}{|l|}{ Systemic symptoms } \\
\hline Vomiting & 119 & 73.0 \\
\hline Abdominal pain & 10 & 6.1 \\
\hline Diarrhea & 3 & 1.8 \\
\hline Priapism* & 52 & 51 \\
\hline Restlessness & 59 & 36.2 \\
\hline Confusion & 37 & 22.7 \\
\hline Convulsion & 13 & 8.0 \\
\hline Coma & 9 & 5.5 \\
\hline Myosis & 5 & 3.1 \\
\hline Hallucination & 4 & 2.5 \\
\hline Sweating & 104 & 63.8 \\
\hline Rhinorrhea & 28 & 17.2 \\
\hline Hypersialorrhea & 19 & 11.7 \\
\hline Lacrymation & 17 & 10.4 \\
\hline Acute pulmonary edema & 25 & 15.3 \\
\hline Bronchial congestion & 16 & 9.8 \\
\hline Shivering & 42 & 32.2 \\
\hline Fever & 47 & 28.8 \\
\hline Hypothermia & 17 & 10.4 \\
\hline Major hyperthermia & 5 & 3.1 \\
\hline Bradypnea & 41 & 25.2 \\
\hline Tachypnea & 50 & 30.7 \\
\hline Collapse & 43 & 26.4 \\
\hline Tachycardia & 70 & 42.9 \\
\hline Bradycardia & 13 & 8.0 \\
\hline
\end{tabular}

${ }^{*}$ Number of male patient $=102$ 
Table 4. Age distribution of stung children according to severity class

\begin{tabular}{c|c|c|c|c|c|c}
\hline \multirow{2}{*}{ Age (months) } & \multicolumn{2}{c|}{ Class I } & \multicolumn{2}{c|}{ Class II } & \multicolumn{2}{c}{ Class III } \\
\hline & Number & $\%$ & Number & $\%$ & Number & $\%$ \\
\hline $1-6$ & 1 & 20 & 0 & 0 & 4 & 80 \\
\hline $6-12$ & 1 & 9.1 & 5 & 45.5 & 5 & 45.5 \\
\hline $12-24$ & 3 & 13 & 3 & 13 & 17 & 73.9 \\
\hline $24-60$ & 9 & 16.4 & 13 & 23.6 & 33 & 60 \\
\hline $60-120$ & 5 & 10.9 & 19 & 41.3 & 22 & 47.8 \\
\hline$\geq 120$ & 11 & 47.8 & 3 & 13 & 9 & 39.1 \\
\hline Total & 30 & 18.4 & 43 & 26.4 & 90 & 55.2 \\
\hline
\end{tabular}

\section{Evolution}

Among the 163 studied cases, 11 deaths were registered, all of which belonged to severity class III. Most fatal cases occurred between July and September. The mean age of these patients was 47 months (standard deviation: 40.4 months; age range: 11 to 132 months) while $81.8 \%$ of them were mountainous regions and $63.6 \%$ were boys. The average time elapsed between sting and admission to the hospital was five hours (standard deviation: 5 hours; range: 2 to 19 hours).

\section{Treatment of Scorpion Stings}

None of our patients received the scorpion antivenom. However, all of them were treated symptomatically depending on the clinical manifestations reported.

\section{DISCUSSION}

Scorpion stings are the most important cause of arachnid envenomation and are responsible for significant morbidity and pediatric mortality in many parts of Asia, Middle East, northern and southern Africa as well as in Central and South America (3-10).

In Morocco, scorpion accidents are the primary source of envenomation and represent between 30 and $50 \%$ of all cases reported to the Moroccan Poison Control Center. The genera Androctonus and Buthus are the most frequently involved in these stings in the country (11). 
Androctonus mauretanicus, a black scorpion, is commonly found in residences, where it seeks dark places. Besides, it also lives in rocky or stony places, gardens, cemeteries and old buildings. This species is one of the most dangerous in Morocco and is involved in numerous serious or often deadly envenomations, especially in children (11). Thus far, two subspecies have been identified: A. mauretanicus mauretanicus and $A$. mauretanicus bourdoni, the former being the more lethal. Buthus occitanus, the most common scorpion species in southwestern Morocco, lives in diverse areas. Since it is not anthropophilous, it can take refuge under stones, rocks and litter - where it can dig burrows - or hide in bark. In Morocco, Buthus stings are considered less dangerous than the ones from other species (11). Although envenomation rates have not changed greatly in recent decades, the incidence of deaths attributed to scorpions has declined due to national strategies against scorpionism that reduced the number of lethal cases and improved both medication use and hospital care. Comparison among data from recent years revealed an increased number of reported cases and decreased morbidity and mortality (12).

Different studies have shown varied age distribution for scorpion stings. Adiguzel et al. (13) observed that children from 9 to 15 years old were more frequently affected (54.1\%) than other age groups $(38.8 \%$ for 3 to 8 years old, and $7.1 \%$ for 0 to 2 years).

Osnaya-Romero et al. (14) reported that there were more cases among infants from 1 to 3 years and the average age was 5.2 years. This average was the same found in our study (4.8 years) with a higher range of 4-10 years old. Also, the younger the patient, the worse the symptoms.

We attribute this high incidence of stings among children to their inquisitive nature and risk-taking behavior (13). In the present study, male victims predominated over female ones (63 versus $37 \%$ ). Several authors assign similar results to more activity displayed by boys than by girls (15). However, there was no difference in severe cases between the sexes. Other studies observed that males had more contact with scorpions than females (16-18); while other reports indicated that females accounted for the majority of victims $(10,19,20)$.

In the current study, extremities were the most affected parts of the body ( $86.5 \%)$, a frequency that is not very different from those reported by other authors who showed that hands, arms, feet and legs were more frequently stung than other body parts 
$(16,21-24)$. These findings may be due to the fact that exposed limbs are usually utilized in most manual activities. Movements also make scorpions retreat; thus, stings may occur in other body parts, such as the neck and head, when the victim is resting or sleeping.

Our study also showed that the majority of scorpion stings occur in July, corroborating data from the medical literature $(2,11,25)$. Like other works, the present work shows that the sting frequency increases in the warmest months throughout the globe $(16,23,26-28)$.

TAS appears to be critical because scorpion venom propagates very rapidly through the victim's body, as proven in clinical and experimental reports (29-33). The elapsed periods between the time of sting and first medical aid were 2.4, 3.3 and 3.5 hours, respectively, for the mild, moderate and severe envenomation groups $(p<0.05)$.

Delayed medical assistance constituted a negative impact on envenomation prognosis; hence, patients that arrived at the hospital more than two hours after the accident presented a greater risk of unfavorable evolution $(25,34,35)$.

In the current work, only a few patients belonged to severity class I (local symptoms) (18.4\%). The most frequently observed symptoms in this group were pain and hyperemia while itching and swelling were less frequent. Edema and local pruritus or paresthesia were rare. These patients were observed for approximately four hours after the sting to detect any general signs related to envenomation.

The percentage of patients belonging to severity class II (shivering, hypersudation, nausea, vomiting, diarrhea and hypertension) was higher (26.4\%). However, present data suggest that younger persons have a higher probability of showing at least one systemic symptom. The reason underlying such symptom severity of envenomated children could be related to their smaller body mass and decreased physiological reserves compared to adults, making them predisposed to develop the most common systemic symptoms. In this case, the predominant signs were vomiting $(73 \%)$, sweating $(73 \%)$, tachycardia $(26.4 \%)$, tachypnea $(30.7 \%)$, priapism $(51 \%)$, shivering $(32.2 \%)$ and fever $(28.8 \%)$ (Table 2). These symptoms indicate an adrenergic autonomic disturbance that specifically involves the sympathetic system and a cholinergic disorder that hinders the parasympathetic system.

Half of patients belonged to severity class III (55.2\%) with cardiovascular, respiratory or neurological distress and often fatal evolution in the absence of appropriate 
management. In our study, the most frequently observed symptoms were acute pulmonary edema, collapse, restlessness, coma, convulsion and confusion (Table 3). What constitutes appropriate treatment for scorpion envenomation remains controversial. While several authors argue that a correct clinical management of Buthidae envenomation treatment eliminates the need for specific antivenom $(3,36-$ $38)$, other authors recommend the use of scorpion antivenom (5, 8, 14, 39-40).

Besides the treatments discussed herein, there are several others that are still used against scorpion sting. These treatments have no scientific basis and sometimes delay the first medical aid for patients with serious envenomation. Some of these prevalent therapies include scarification in the sting area - to induce bleeding which may provoke venom release ( $40 \%$ of our stung children were incised) -, suction, henna, oil or drinking milk. All these measures are strongly contraindicated.

\section{CONCLUSIONS}

As far as we know, this is the first epidemiological study attempted to establish the clinical features associated with scorpion envenomation in children in Morocco. The present investigation showed that children present a higher risk of dying if they arrive at the hospital presenting severity class III symptoms (acute pulmonary edema, coma and shock). A new management to provide support for patients was standardized at the national level; its objectives are reduction of lethal cases, improvement of medication use, transference of patients and hospital care. This standardization is an essential component of the national strategy against scorpion envenomation.

\section{REFERENCES}

1. Soulaymani R, Faraj Z, Semlali I. Epidémiologie des piqûres de scorpion au Maroc. Rev Epidemiol Santé Publ. 2002;50(4):341-7.

2. Abroug F, Nouira S, Saguiga H. Envenimations scorpioniques: avancées chimiques, physiopathologiques et thérapeutiques [Monograph]. 1994. 1-68 p.

3. Abrough F, Elastrous S, Nouira S, Haguiga H, Touzi N, Bouchoucha S. Serotherapy in scorpion envenomation: a randomized controlled trial. Lancet. 1999;354(9182):906-9.

4. Dehesa-Daliva M, Possani LD. Scorpion and serotherapy in Mexico. Toxicon. $1994 ; 32(9): 1015-8$. 
5. Ghalim N, El-Hafny B, Sebti F, Heikel J, Lazar N, Moustanir R, Benslimane A. Scorpion envenomation and serotherapy in Morocco. Am J Trop Med Hyg. 2000;62(2):277-83.

6. Groshong TD. Scorpion envenomation in eastern Saudi Arabia. Ann Emerg Med. 1993;22(9):1431-7.

7. Freire ML, Campos JA, Amaral CFS. Approaches to the treatment of scorpion envenoming. Toxicon. 1994;32(9):1009-14.

8. Ismail M. The treatment of the scorpion envenoming syndrome: the Saudi experience with serotherapy. Toxicon. 1994;32(9):1019-26.

9. Del Valle Luna MG, Luna MM. Escorpionismo por Tityus trivittatus. Arch Argent Pediatr. 1997;95(6):406-12.

10. Bergman NJ. Clinical description of Parabuthus transvaalicus scorpionism in Zimbabwe. Toxicon. 1997;35(5):759-71.

11. Touloun O, Slimani T, Boumezzough A. Epidemiological survey of scorpion envenomation in southwestern Morocco. J Venom Anim Toxins. 2001;7(2):199-218.

12. Soulaymani-Bencheikh R, Idrissi M, Tamim O, Semlali I, Mokhtari A, Taybi M, Soulaymani A. Scorpion stings in one province of Morocco: epidemiological, clinical and prognosis aspects. J Venom Anim Toxins incl Trop Dis. 2007;13(2):462-71.

13. Adiguzel S, Ozkan O, Inceoglu B. Epidemiological and clinical characteristics of scorpionism in children in Sanliurfa, Turkey. Toxicon. 2007;49(6):875-80.

14. Osnaya-Romero N, de Jesus Medina-Hernandez T, Flores-Hernandez SS, LeonRojas G. Clinical symptoms observed in children envenomed by scorpion stings, at the children's hospital from the state of Morelos, Mexico. Toxicon. 2001;39(6):781-5.

15. Hernandez IHF. Picadura de alacran. Epidemiologia (Mex.). 1997;11(1):1-2.

16. de Roodt AR, Garcia SI, Salomon OD, Segre L, Dolab JA, Funes RF, de Titto EH. Epidemiological and clinical aspects of scorpionism by Tityus trivittatus in Argentina. Toxicon. 2003;41(8):971-7.

17. Pardal PP, Castro LC, Jenings E, Pardal JS, Monteiro MR. Epidemiological and clinical aspects of scorpion envenomation in the region of Santarem, Para, Brazil. Rev Soc Bras Med Trop. 2003;36(3):349-53.

18. Al-Asmari AK, Al-Saif AA. Scorpion sting syndrome in a general hospital in Saudi Arabia. Saudi Med J. 2004;25(1):64-70.

19. Forrester MB, Stanley SK. Epidemiology of scorpion envenomations in Texas. Vet Hum Toxicol. 2004;46(4):219-21. 
20. Ozkan O, Adiguzel S, Yakistiran S, Cesaretli Y, Mehmet O, Karaer Z. Androctonus crassicauda (Olivier 1807) scorpionism in the Saniliurfa provinces of Turkey. Turk Parazitol Derg. 2006;30(3):239-45.

21. Farghly WM, Ali FA. A clinical and neurophysiological study of scorpion envenomation in Assiut, Upper Egypt. Acta Paediatr. 1999;88(3):290-4.

22. Silva RLM, Andrea M, Amorim TK. Envenomation by Tityus stigmurus (Scorpiones: Buthidae) in Bahia, Brazil. Rev Soc Bras Med Trop. 2000;33(3):239-45. 23. Al-Sadoon MK, Jarrar BM. Epidemiological study of scorpion stings in Saudi Arabia between 1993 and 1997. J Venom Anim Toxins incl Trop Dis. 2003;9(1):5464.

24. Gordillo ME, Bugliolo AG, Delloni A. Escorpionismo en pediatria. Arch Argent Pediatr. 2000;98(5):296-303.

25. Soulaymani R, Semlali I, Ghani A, Badri M, Soulaymani A. Implantation et analyse d'un registre des piqûres de scorpion au Maroc. Rev Epidemiol Santé Publ. 2004;3(16):487-98.

26. Soker M, Haspolat K. Scorpion sting in children. Çocuk Sağlığı Hastalıkları Derg. 2000;43(1):43-51.

27. Altinkaynak S, Ertekin V, Alp H. Scorpion envenomation in children. Turk Arch Pediatr. 2002;37:48-54.

28. Ozkan O, Kat I. Mesobuthus eupeus scorpionism in Sanliurfa region of Turkey. J Venom Anim Toxins incl Trop Dis. 2005;11(4):479-91.

29. Ismail M, Abd-El Salam A. Are the toxicological effects of scorpion envenomation related to tissue venom concentration? Toxicon. 1988;26(3):233-56.

30. Chavez-Olortegui C, Fonseca SC, Campolina D, Amaral CF, Diniz CR. ELISA for the detection of toxic antigens in experimental and clinical envenoming by Tityus serrulatus scorpion venom. Toxicon. 1994;32(12):1649-56.

31. de Rezende NA, Dias MB, Campolina D, Chavez-Olortegui C, Amaral CFS. Standadization of an enzime linked immunosorbent assay (ELISA) for detecting circulating venom antigens in patients stung by the scorpion Tityus serrulatus. Rev Inst Med Trop São Paulo. 1995;37(1):71-4.

32. Santana GC, Freire ACT, Ferreira APL, Chaves-Olortegui C, Diniz CR, FreireMaia L. Pharmacokinetics of Tityus serrulatus scorpion venom determined by enzyme-linked immunosorbent assay in the rat. Toxicon. 1996;34(9):1063-6. 
33. Krifi MN, Kharrat H, Zghal K, Abdouli M, Abroug F, Bouchoucha S, Dellagi K, El Ayeb M. Development of an ELISA for the detection of scorpion venoms in sera of humans envenomed by Androctonus australis garzonii (AAG) and Buthus occitanus tunetanus (BOT): correlation with clinical severity of envenoming in Tunisia. Toxicon. 1998;36(6):887-900.

34. Goyffon M, Elayeb M. Epidemiologie du scorpionisme. Infotox. 2002;15:2-6.

35. Jeddi MH Ben Hamida CH, Damak J, Jeddi M, Ayadi N. Piqûre par scorpion chez I'homme en Tunisie: étude épidémiologique. Publ Fac Med Sfax. 1988;1-463.

36. Gueron M, Ovsyshcher I. What is the treatment for the cardiovascular manifestations of scorpion envenomation? Toxicon. 1987;25(2):121-4.

37. Gueron M, Sofer S. The role of intensivist in the treatment of the cardiovascular manifestations of scorpion envenomation. Toxicon. 1994;32(9):1027-9.

38. Sofer S, Shahak E, Gueron M. Scorpion envenomation and antivenom therapy. J Pediatr. 1994;124(6):973-8.

39. Freire-Maia L, Campos JA. On the treatment of the cardiovascular manifestations of scorpion envenomation. Toxicon. 1987;25(2):125-30.

40. Possani LD. Antivenom for scorpion sting. Lancet. 2000;355(9197):67. 